\title{
ARCHITECTURAL DESIGN \& CONSTRUCTION IN THE XX CENTURY: FROM MECHANISATION TO AUTOMATION
}

\author{
María Aurora Flórez de la Colina \\ Architect, PhD. Associate Professor. \\ Building Technology Department. \\ Polytechnic University of Madrid (Spain)
}

\begin{abstract}
Introducing methods of Construction Automation in Architectural Design faces problems not always related to technical issues. This papers studies some of the past experiences which have transformed the Architecture of the XXth Century: how some of the changes in the industry have been interpreted by artists and society, their influence in the construction field through architects and engineers. It analyses the problems created by the lack of co-ordination and integration of all these features and proposes some solutions. based on previous studies in Automation and its relation to Architecture Design.
\end{abstract}

Keywords: Architecture Design, Construction Automation.

\section{SHOULD ARCHITECTURE DESIGN BE ORIENTED TOWARDS CONSTRUCTION AUTOMATION?}

To this question, if nothing else is added, most architects and non professional people would answer negatively, calling for freedom in art, and may be also in choosing what surrounds theirs lives: homes, cities, places of leisure, but also offices, factories, schools... Everybody would prefer to choose from a variety of products available, which includes buildings and cities, than to be obliged to a fixed standard, even when it is all they can afford. It may be true that if you include construction automation you can reduce prices, but in the early stages, the resulting architectural design can be too homogenous which may be boring in its uniformity.

It may look just the opposite if we think seriously of all the new possibilities automation could bring in any fields, but in previous research done on Home Automation I have found this a surprising but not unexpected fact, which also appears in relation to Construction Automation: initial rejection.

New handicrafts had always aroused marvel and fear at the same time. When they had evolved into the more complex artefacts developed during the eighteenth century, at the beginning of what we call the Industrial Revolution, feelings towards them were similar. So, it may be logical to expect the same reactions when new technologies are introduced.
The reason for this dread appears in the title "Mechanization takes command" (1) by Siegfried Giedion. The threat behind the machine designed to help mankind is that it may be more powerful than us. It is portrayed in this way in the famous Charlie Chaplin film "Modern Times" (2), where we see the main character enslaved by his work in the assembly line, so common and at the same time one of the most basic pillars of the first period of the Industrial Revolution. [Fig.1] If we think of all the images produced both by cinema and television we may have to agree that most of them are not very helpful to dispel this fear .

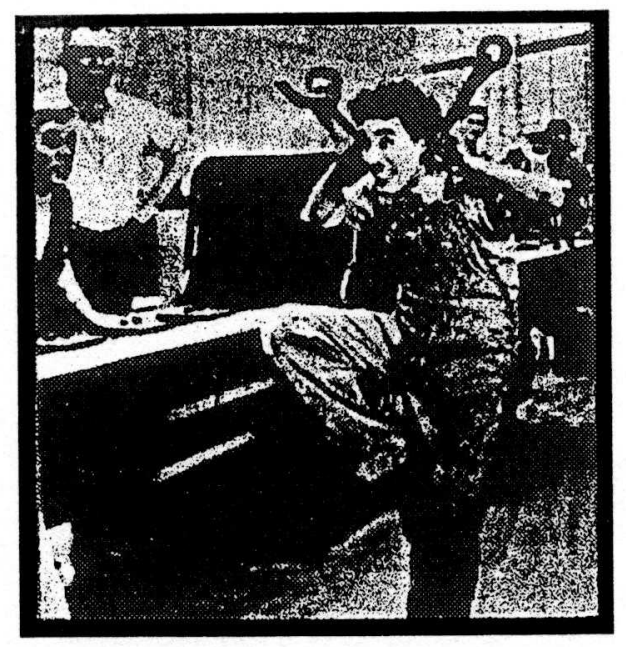

Figure 1. Work in the assembly line. From the film "Modern Times" 


\section{MACHINES IN CONSTRUCTION.}

In the most common and wide meaning of the term, we may find machines ifrom the first millennium B. C. From this period of time onwards, it is possible to find texts trying to understand their basics and improve them. Most of these tools are weapons of war but they use the same principles as those used on building sites. This is written in the first treatise on Architecture by the Roman Marco Vitruvio. Unfortunately, the drawings of the "Ten books of Architecture" are missing (3).

But we may find some machines in medieval miniatures with building sites and in the collection of drawings of Villard de Honnecourt, as he indicates "giving advise on building techniques for masonry, machines for joinery, the art of portraiture, drawing and geometry" (4) [ Fig. 2] a very interesting graphic reference.

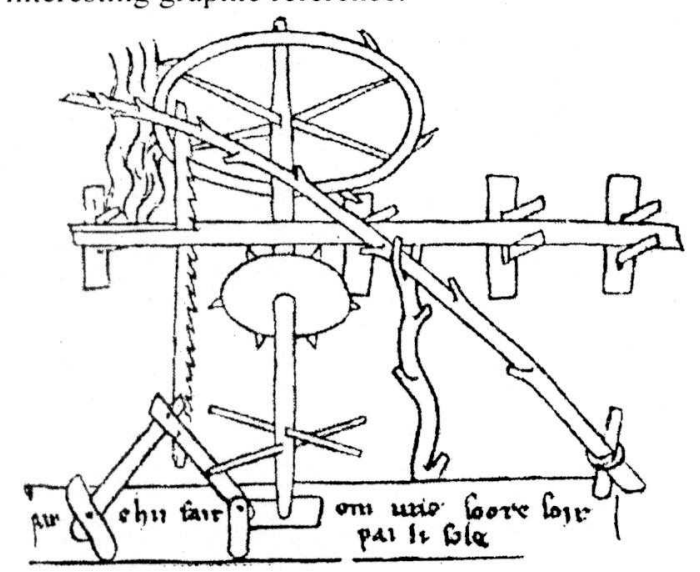

Figure 2. Machines for joinery. Hydraulic saw. From Villard de Honnecourt.

Treatises on machines as Mariano Taccola's or the explanations of the Leonardo Da Vinci manuscripts give us wider information of their use in construction. We have more facts from the "Teatra Maquinorum" from XVI, XVII, and XVIII centuries (5).

It is possible to trace the evolution of the progressive mechanisation of some tasks on building sites, such as the elevation or movement of heavy objects .

Machines were introduced obviously for economic reasons but they made possible achievements which where impossible before, they created new conditions.

The use of more powerful kinds of energies (steam, combustion engines, electricity etc...), in combination with a better knowledge of the mechanical principles and the new materials, developed throught the XIX century and have shaped this $X X$ century, now at its end. On construction sites where it has been also like that, tools are now much more complex and efficient.

\section{AUTOMATION ON BUILDING SITES.}

The transformation from crafmanship to industrial production process has been slower in the construction field than in other economic areas. The reasons for it may not be too simple to point out.

Some features of industrialised production, such as specialisation, are in the earliest historic periods of construction. You may find them in the descriptions of how to produce ceramic pieces to be used in buildings. What we called Modern Architects, like Le Corbusier, have been quite enthusiastic about the possibility of mass producing houses with the same process as cars (6). Even now, Prefabrication of buildings is still done on a small scale.

But what we really consider the beginning of automation should be, when a part of this sequence of the production process is done through mechanisms. Some of the earlier examples using water or wind power may seem very simple today, but we may still learn from them. What we consider nowadays as construction automation, is much more complex. Sometimes its objectives are not so clear as they should be, and that is one of the reasons of errors and failures.

The machines designed in this last period of the $X X$ th century are able not only to follow a predetermined sequence but to choose between some programmed actions in relation to the data given to them. They are already used quite widely in Industry, Transportation, and Buildings Services, for Military purposes, in Medicine etc...

In this century, automation has been frequently related to robotics, as this word refers to an evolved kind of machines, those which are able to perform some kinds of movements. That applies to the tools we use on building sites.

And, here is the main problem: the variability of scenarios we find in construction which make this predetermination difficult.

So, how to make automation possible? By simplifying Architectural Design features to make it easier?

I do not think this is a good solution and in some cases it has contributed to giving a wrong idea of the possibilities of automation. 
4. AUTOMATION AND ARCHITECTURAL DESIGN.

There are some well known Architects interested in the new possibilities automation could offer them, being aware of something more than what is available now.

What is already used in the so called "Smart Buildings", is automation in several levels of Communications and Services.

There are research groups in most countries which are developing these technologies to study how these systems are used which is not always related with the initial purpose they were designed (7). That may also be possible in Construction automation, learning from past experience how to avoid problems which can, in some ways, be similar.

It is very common to solve technical problems, for instance how the automated system performs some tasks on a site. Then, not to study the complete situation beforehand, which includes the opinions of the people involved in the activities related to the system which is being automated.

\section{CONCLUSIONS.}

The human factor is essential in the process of automating construction and should be considered carefully to ensure success. Experts on this subject (sicologues, sociologist etc..), should be included in research groups.

Past experience, mass media and cinema may help us to point out the problems related to technology that have not been taken into consideration.

Lack of co-ordination and prevision for the needs of the people involved in this change, could make it a failure.

\section{REFERENCES}

(1) "Mechanization Takes Command" (1947) by Siegfried Giedion. A very interesting study on the consequences of mechanisation upon the human surroundings.

(2) "Modern Times" (193 ), film by Charlie Chaplin, on the effects of mass production upon human beeings.

(3) "The Ten books of Architecture" ( 1st century ) by Marco Vitruvio. Considered to be the first treatise on Architecture.
(4) "Album" (XIII century), manuscript by Villard de Honnecourt. Ms. Fr. 19093. Bibliothèque Nationale, Paris, France.

(5) On this subject, "Maquinaria y' medios auxiliares para la construcción durante la Edad Media: Análisis de la iconografía ". II Congreso de Historia de la Construcción, La Coruña, october 1998. pp. 387-390.

(6) "Vèrs une architecture" (1923), by Le Corbusier, "Maisons en série", on what should be modified in architectural design and in the approach to the concept of houses, to be able to start mass production.

(7) "La Domotique: mise en oevre et finalités sociales" (april 1990) Philippe Dard. CSTB Magazine no 33. Paris (France). "Assesing Smart Home Debut. Wiring now available, but there are drawbacks" (september 1991), Mike McClintock. Washington Post (U.S.A)

\section{BIBLIOGRAPHY}

Dard, Philippe. "La Domotique: mise en oevere et finalités sociales" (april 1990), CSTB Magazine $n^{\circ}$ 33. Paris (France).

Giedion, Siegfried. "Mechanization Takes Command" (1948). Ed. Oxford University Press/ W.W Norton \& Company, Inc. London.

Honnecourt, Villard de " Album” (XIII century), manuscript Ms. Fr. 19093, Bibliothèque Nationale. Paris, France

Le Corbusier. "Vèrs une architecture" (1923). Ed.

Crès et Cie, Paris (France).

McClintock, Mike. "Assesing Smart Home Debut. Wiring now available, but there are drawbacks" (september 1991), Washington Post (U.S.A)

Pérez Martín, J.L; Ignacio Vicens, G; Flórez de la Colina, M.A. "Maquinaria y medios auxiliares para la construcción durante la Edad Media: Análisis de la iconografía ". II Congreso de Historia de la Construcción, october 1998, La Coruña (Spain). pp. 387-390.

Vitruvio, Marco. "De Architectura Libri Decem" ("The Ten books of Architecture"). Ed. Princeps 1486. 